\title{
IDENTIFICATION AND EFFECTS OF MIXED INFECTION OF Potyvirus ISOLATES WITH Cucumber mosaic virus IN CUCURBITS ${ }^{1}$
}

\author{
GRAZIELA DA SILVA BARBOSA ${ }^{2 *}$, JOSÉ ALBERSIO DE ARAÚJO LIMA ${ }^{3}$, MANOEL ABILIO DE QUEIRÓZ2 \\ RITA DE CÁSSIA SOUZA DIAS ${ }^{4}$, CRISTIANO SOUZA LIMA ${ }^{3}$
}

\begin{abstract}
Mixed infections in cucurbits are frequently observed in natural conditions between viruses from the Potyvirus genus and Cucumber mosaic virus (CMV), which significantly decreases productivity. The objectives of the present study was to compare the host range of PRSV-W, WMV, and ZYMV isolates and evaluate the effects of mixed infections with CMV in zucchini plants (Cucurbita pepo L.). Host range studies comprising 23 plant species confirmed some similarities and biological differences among the isolates of PRSV-W, ZYMV, and WMV. RT-PCR confirmed the amplification of DNA fragments of the PRSV-W, WMV, and ZYMV coat protein gene $(c p)$ and cytoplasm inclusion gene $(c i)$. The virus interaction studies in zucchini Caserta plants indicated synergistic interactions, particularly among species from the Potyvirus genus, and some CMV interference with some virus combinations.
\end{abstract}

Keywords: Papaya ringspot virus. Zucchini yellow mosaic virus. Watermelon mosaic virus. Synergistic interaction.

\section{IDENTIFICAÇÃO E EFEITOS DA INFECÇÃO MISTA DE ISOLADOS DE Potyvirus E Cucumber mosaic virus EM CUCURBITÁCEAS}

RESUMO - Infecções mistas em cucurbitáceas são observadas com grande frequência em condições naturais entre os vírus do gênero Potyvirus e o Cucumber mosaic virus (CMV), reduzindo significativamente a produtividade das culturas. Os objetivos deste trabalho foram comparar a gama de hospedeiras de isolados de PRSV-W, WMV e ZYMV e avaliar os efeitos de infecções mistas entre esses isolados e um isolado de CMV em abobrinha (Cucurbita pepo) cv. Caserta. Estudos de gama de plantas hospedeiras, envolvendo 23 espécies vegetais confirmaram similaridades e diferenças biológicas entre PRSV-W, ZYMV e WMV. Estudos moleculares com RT-PCR possibilitaram a amplificação de fragmentos de DNA para as regiões do gene da $\mathrm{CP}$ $(c p)$ e do gene da CI ( $c i)$ de PRSV-W, WMV e ZYMV. Estudos sobre interação sinérgica entre os vírus do gênero Potyvirus e CMV em abobrinha cv. Caserta evidenciaram efeitos sinérgicos, sobretudo entre as espécies do gênero Potyvirus e interferência do CMV em algumas combinações.

Palavras-chave: Papaya ringspot virus. Zucchini yellow mosaic virus. Watermelon mosaic virus. Efeito sinérgico.

\footnotetext{
*Corresponding author

${ }^{1}$ Received for publication in $06 / 07 / 2016$; accepted in $07 / 11 / 2016$.

Paper extracted from the first author's doctoral dissertation, funded by CAPES and CNPq

${ }^{2}$ Plant Molecular Biology Laboratory, Technology and Social Sciences Department, Universidade do Estado da Bahia, Juazeiro, BA, Brazil; grazzy22@hotmail.com, manoelabiliomaq@gmail.com.

${ }^{3}$ Plant Virology Laboratory, Department of Phytosanitation, Universidade Federal do Ceará, Fortaleza, CE, Brazil; albersio@ufc.br, csl@ufc.br.

${ }^{4}$ Embrapa Semiárido, Petrolina, PE, Brazil; rita.dias@embrapa.br.
} 


\section{INTRODUCTION}

Based on its soil and climate properties, northeastern Brazil has great potential to produce several cultivated cucurbit species, specifically melon (Cucumis melo L.), watermelon (Citrullus lanatus (Thunb.) Matsum; Nakai), and squash (Cucurbita spp.). Several biological factors, mainly insect infestation and disease, can affect cucurbit production. Viral diseases are of great importance in this respect, because they can affect fruit quality and quantity, reducing production by up to $100 \%$ (LIMA et al., 2012a).

Approximately 20 virus species have been reported to infect cultivated cucurbits worldwide, and nine of them are considered of economic importance to crops in Brazil. Predominant viral species include those of the Potyvirus genus(family Potyviridae), such as Papaya ringspot virus type Watermelon (PRSV-W), Watermelon mosaic virus (WMV), and Zucchini yellow mosaic virus (ZYMV) (FINETTI-SIALER et al., 2012; LIMA et al., 2015). The infection incidence with these viruses is high and they can occur as single or mixed infections with other virus species, including Cucumber mosaic virus (CMV; Cucumovirus genus). These viral species can be naturally transmitted by the same aphid species, in a non-persistent manner (OLIVEIRA et al., 2000).

Mixed virus infections in plants can exacerbate and increase the severity of disease symptoms, significantly increasing crop production losses (MALIK et al., 2010). CMV is a viral specie that infects plants, and has the largest known host range. It can also synergistically interact with viruses from the genus Potyvirus, increasing disease symptoms and damage to the crop (CHOI et al., 2002). Thus, the present research was conducted to compare the host range of PRSV-W, WMV, and ZYMV isolates and evaluate the effects of mixed infections with CMV in zucchini (Cucurbita pepo L.).

\section{MATERIAL AND METHODS}

Leaf samples with virus symptoms were collected in cucurbit fields of squash, pumpkin (Cucurbita moschata Duch.), melon, and watermelon from small growers in the sub-medium San Francisco Valley, during the period of 2011 to 2013. The fields were located at irrigated areas of Nilo Coelho and Experimental Bebedouro Station watermelon fields from Embrapa Semiarid, in Petrolina County, Pernambuco State $\left(09^{\circ} 23^{\prime} 55^{\prime \prime} \mathrm{S}\right.$, $\left.40^{\circ} 30^{\prime} 03^{\prime \prime} \mathrm{W}\right)$ and small grower areas from Juazeiro County, Bahia State ( $\left.09^{\circ} 24^{\prime} 42^{\prime \prime} \mathrm{S}, 40^{\circ} 29^{\prime} 55^{\prime \prime} \mathrm{W}\right)$. A total of 98 leaf samples with typical virus symptoms were collected and transported to the
Plant Virus Laboratory (LabVV) at the Universidade Federal do Ceará (UFC).

All leaf samples were tested against polyclonal antisera to PRSV-W, WMV, ZYMV, and CMV using plate trapped-enzyme linked immunosorbent assay (PTA-ELISA). The antisera for PRSV-W, ZYMV, WMV, and CMV and the respective virus isolates used as controls for the PTA-ELISA were from the antiserum collection and live virus collection of the LabVV.

Host range experiments were developed at a greenhouse in the LabVV, involving 23 plant species from the following botanical families: Amaranthaceae, Brassicaceae, Chenopodiaceae, Cucurbitaceae, Fabaceae, Malvaceae, Pedaliaceae, and Solanaceae. The cotyledons or the first true leaves from the tested plants were separately inoculated with PRSV-W, WMV, and ZYMV isolates prepared in $0.05 \mathrm{M}$ potassium phosphate buffer, pH 7.5 [1:2] (mass/volume). Four non-inoculated plants from each plant species/ cultivar were maintained as controls. The inoculated plants were observed daily for symptom development and those that did not present symptoms 10 days after inoculation were re-inoculated with the corresponding virus isolate. Twenty-five days after the first inoculations, all inoculated plants were tested by PTA-ELISA using the corresponding antisera.

Leaf samples collected from pumpkin, squash, melon, and watermelon, and those plants used for host range studies, were tested using antisera to PRSV-W, WMV, ZYMV, and CMV by PTA-ELISA according to Mowat and Dawson (1987). The absorbance readings were considered positive when the values were 2.5 -fold greater than the average of the absorbance values obtained from healthy plant extracts, used as a control in accordance with Lima et al. (2015).

All leaf samples from cucurbit plants collected in the field were also tested against antiserum for Squash mosaic virus (SqMV) using Ouchterlony double-diffusion tests.

Leaf samples from zucchini maintained in a greenhouse, infected with PRSV-W, WMV, and ZYMV and exhibited typical virus symptoms were used for total RNA extraction using the guanidine-phenol-chloroform thiocyanate method (Brazol) (CHOMCZYNSKI; SACCHI, 1987).

A reverse transcription protocol was developed using $3.0 \mu \mathrm{L}$ of extracted RNA, $2 \mu \mathrm{L}$ of reverse primers, and $5.0 \mu \mathrm{L}$ of nuclease-free water in microtubes, which were incubated at $70{ }^{\circ} \mathrm{C}$ for $5 \mathrm{~min}$ in a thermo cycle and transferred to ice for $5 \mathrm{~min}$. Subsequently, $5.75 \mu \mathrm{L}$ of $5 \times$ buffer, $2 \mu \mathrm{L}$ of $0.1 \mathrm{M}$ $\mathrm{dTT}, 1.25 \mu \mathrm{L} 10 \mathrm{mM} \mathrm{dNTPs}$, and $1.0 \mu \mathrm{L}$ of M-MLV reverse transcriptase enzyme $\left(\right.$ Promega $^{\circledR}$ ) were added, and the tubes were incubated at $42{ }^{\circ} \mathrm{C}$ for 60 $\min$.

Primers for amplification of genomic portions 
of PRSV-W, WMV, and ZYMV isolates were designed using the Primer3 Plus Program and analyzed by OligoAnalyzer 3.1. Sense and anti-sense primers were designed for PRSV-W $c p$ and $c i$ with the following sequences and composition: CP(F) 5'-TGAACGTGAGAGGGGAGACT-3'， CP (R) 5'-CAGCAAACACACAAGCGCGA-3', CI(F) 5'-CGACGTGGACAAGAGTGATT-3', and CI(R) 5'-CACTATTTGCACCAGTACCG-3'; for WMV $c p$ and $c i$ : CP(F) 5'-AACTCGCTGCATCCGGAAAA3', CP(R) 5'-CGCAAATGCTAACTGTGACC-3', CI (F) 5'-GGCTTTACTGACCATGTGCA-3', and CI (R) 5'-CCCATCTGCATAGTTCTACC-3'; for ZYMV $\quad c p: \quad \mathrm{CP}(\mathrm{F}) \quad$ 5'CTACCTACAAGCCCTCCATC-3', CP(R) 5'CAGCGAATCGATAACCTAGG-3'. The primers were designed to amplify a 999-bp fragment of the $c p$ region of PRSV-W, an 814-bp fragment of the $c i$ region of PRSV-W, a 1,025-bp fragment of the WMV $c p$ region, a 965-bp fragment of the WMV $c i$ region, and a 935-bp fragment of the ZYMV $c p$ region.

The PCR reactions were performed using the GotTaq ${ }^{\circledR}$ DNA Polymerase Promega ${ }^{\circledR}$ kit with a total reaction volume of $25 \mu \mathrm{L}$. The virus genome fragments were amplified by PCR in the Mastercycler gradient (Eppendorf) and the amplified products were visualized after $0.8 \%$ agarose gel electrophoresis, which was performed at $90 \mathrm{~V}$ in a horizontal system for $50 \mathrm{~min}$. After electrophoresis, the gel was stained with ethidium bromide $(0.1 \mu \mathrm{g} /$ $\mathrm{mL}$ ) and the electrophoretic pattern was visualized and documented by an ultraviolet photo documenter 212 PRO Gel Logic.

For evaluating the effects of mixed infection, using viruses from the Potyvirus genus and CMV, zucchini seeds of the cultivar Caserta were germinated in polystyrene trays containing 128 cells, with a sterile horticultural substrate, seeding at one seed per cell. After eight days, the seedlings were transplanted to plastic pots with two parts sterile agriculture soil mixed with one part sterile cattle manure, and maintained in greenhouse conditions. The experiments were entirely randomized, with four plants per pot and three pots per treatment. Four healthy plants were maintained without inoculation as a negative control.

Seven days after transplantation, the young plants were inoculated with plant extracts obtained from PRSV-W-, WMV-, ZYMV-, and $\mathrm{CMV}$-infected plants. The virus inoculations were performed separately, with each virus inoculated on the upper surfaces of plant cotyledons with double, triple, and quadruple combinations of viruses. Inoculated plants were evaluated daily for the symptom development. Considering the mild symptoms caused by CMV and its low concentration, as evaluated by PTA-ELISA, all plants in which it was also inoculated were also evaluated by RT-PCR using a specific pair of primers for the $\mathrm{CP}$ region of $\mathrm{CMV}$ (BARBA; JELKMAN; MARTIN, 1998), which amplifies a sequence of $500 \mathrm{bp}$.

Possible synergistic interactions between viral species were evaluated based on the effects of single and mixed infections on plant heights and fresh masses. The plant heights were determined by measuring the stem size (in $\mathrm{cm}$ ), measured from the soil line to the stem apices at 25 days after inoculation. To evaluate the aerial part fresh masses, the plants from each treatment were removed from the soil according to the methodology proposed by Murphy and Bowen (2006) at 25 days post-inoculation.

The data were submitted to analyses of variance using the $F$ test, and when this was significant, the averages were compared using Tukey's test with a 5\% significance of probability level, utilizing the software GENES (CRUZ, 2013). Percent reductions in plant growth and fresh masses were estimated in relation to the plant growth and fresh masses of healthy zucchini plants. The obtained values were used to estimate waited response $\left(\mathrm{C}_{\mathrm{WT}}\right)$ for two virus co-infections, using the Abbott equation utilized by Gisi (1996): $\mathrm{C}_{\mathrm{WT}}=\mathrm{A}+\mathrm{B}$ $(\mathrm{AB} / 100)$. To evaluate synergism caused by three or four viruses, the Abbot equation was used with some modifications. Considering that $\mathrm{C}_{\mathrm{WT}}$ was compared with an observed response $\left(\mathrm{C}_{\mathrm{OBS}}\right), \mathrm{C}_{\mathrm{OBS}}>\mathrm{C}_{\mathrm{WT}}$ was used to identify a synergistic interaction.

\section{RESULTS AND DISCUSSION}

Approximately $66 \%$ of the 98 cucurbit symptomatic samples collected in the San Francisco Valley were infected with one or more viruses, and especially with species from the Potyvirus genus. Approximately 51 cucurbit samples were infected with PRSV-W, 43 with ZYMV, and 39 samples with WMV. Similar results were observed by Silveira et al. (2009); based on serological surveys that were performed with similar climate conditions on irrigated cucurbit crops in the counties of Petrolina and Juazeiro, most samples were infected with PRSV-W. The predominant virus species varied as a function of the crops and the origin of the samples. In addition, those results could be due to the intrinsic factors of the crops, including susceptibility, but also could vary with the agricultural practices employed in the region (JUAREZ et al., 2013).

CMV was detected in only one watermelon sample in the form of a mixed infection with WMV. Mixed infections of CMV and Potyvirus have also been reported in cucurbit crops. The origin, the plant species involved, the efficiency of the aphid species in virus transmission, and Potyvirus interference could affect the degree of CMV incidence, which could account for its low incidence in the field in several countries, including Brazil (PINTO et al., 
2008).

None of the samples from cucurbit crops were infected with SqMV, confirming its low incidence in the northeast. Although Ouchterlony double-diffusion tests have lower sensitivity than ELISA, this method was used because SqMV presents difficulties concerning the adhesion of its particles to the bottom of ELISA plates (LIMA et al., $2012 b)$. The absence of SqMV in the indexed samples could be associated with its reduced host range and the absence or scarcity of its natural biological vector, due to intense use of chemical control in cucurbit fields. This would diminish the insect population, particularly the coleopterons that are natural SqMV vectors (SILVEIRA et al., 2009; SILVA et al., 2016).

The occurrence of double and triple infections, with species from the Potyvirus genus, was detected in this study with a high incidence of triple infections (in $40 \%$ of the samples). These results, supported by results from related literature, provide relevant evidence regarding the prevalence of viruses from the Potyvirus genus in the cucurbit crop production fields in the northeastern Brazil. These occurred as single and mixed infections throughout the evaluated years, representing important problems for the region.

Through assessing the disease symptoms and serological results of 23 plant species inoculated with PRSV-W, WMV, and ZYMV, biological differences were confirmed (Table 1). These virus species induced systemic infection in cucurbits, mainly in melon and C. moschata 'Mogango', which was in accordance with results obtained by Yakoubi et al. (2008).

All virus species induced local lesions in Chenopodium amaranticolor, and WMV and ZYMV caused local lesions in Gomphrena globosa. In addition, PRSV-W and ZYMV induced local chlorotic lesions in $C$. quinoa and only PRSV-W induced local lesions in Chenopodium murale (Table 1). Results obtained by Hosseini et al. (2007) and Coutts et al. (2011) demonstrated that isolates of ZYMV from Iran and Australia induced local chlorotic lesions in Chenopodium quinoa and $C$. amaranticolor.

It was observed that all evaluated plant species from the Cucurbitaceae family were infected with PRSV-W, except for Crimson Sweet and Luffa cylindrical (Table 1). Similar results were also observed by Kumar, Sankarlingam, and Rabindran (2014) in pumpkin. Except L. cylindrica, WMV isolates infected all cucurbits (Table 1). Finetti-Sialer et al. (2012) also observed that an isolate of WMV caused symptom reactions in five cucurbit species and in two Chenopodium spp. Although positive based on PTA-ELISA, the Sesamum indicum plants inoculated with WMV did not show disease symptoms (Table 1). Some viral isolates can systemically infect certain plant species or cultivars without causing visible disease symptoms (DESBIEZ; LECOQ, 1997). This uncommon property observed for $S$. indicum could suggest its use as an indicator plant for WMV. The incorporation of indicator plants in the host range is very useful, since it can help in the distinction of virus isolates/species (AL-SALEH et al., 2014). In contrast, the tolerance to WMV observed for $S$. indicum could mean that it is another natural source of WMV in the field. ZYMV induced systemic symptoms in all inoculated cucurbits (Table 1); however, despite presenting disease symptoms, watermelon cultivars C. Sweet and Omaru Yamato presented low absorption values in PTA-ELISA, indicating a low virus concentration in infected plant cells.

RT-PCR analyses confirmed amplification of PRSV-W, WMV, and ZYMV DNA fragments, which were close to the expected sizes for PRSV-W, with approximately 999 bp for the $\mathrm{CP}$ gene $(c p)$ region and $814 \mathrm{bp}$ for the $\mathrm{CI}$ gene $(\mathrm{ci})$ region; for WMV with 1,025 bp for $c p$ and $965 \mathrm{bp}$ for $c i$; and for ZYMV with 935 bp for $c p$. As expected, no DNA fragments were amplified from healthy plant leaf tissues.

Cucurbita pepo 'Caserta' plants presented typical and distinguishable disease symptoms when they were individually inoculated with PRSV-W, ZYMV, WMV, and CMV, 12 days after inoculation. The disease symptoms were less apparent in plants inoculated with only CMV (yellow points) or with WMV (mild mosaic). When $C$. pepo plants were co-infected with WMV and with CMV, they presented comparable symptoms to the plants infected only with WMV. Although CMV was detected by RT-PCR (Figure 1), upon double infection with WMV, it was not detectable by PTA-ELISA, indicating that the complete replication of CMV was probably inhibited such that its particle concentration was reduced, and thus was not detected by PTA-ELISA.

Single infection of PRSV-W and mixed infection with CMV caused severe mosaic with leaf deformation. The most severe symptoms were observed in plants inoculated with ZYMV alone or with mixed infections, resulting in severe mosaic, leaf deformations, and/or shoe string. Severe symptoms induced by ZYMV has been reported in single and in mixed infections with other viruses of the Potyvirus genus, in several cucurbit species (OLIVEIRA et al., 2000; YAKOUBI et al., 2008); this explains the predominance of severe disease symptoms in single and mixed infections involving ZYMV observed here. 
Table 1. Disease symptoms and PTA-ELISA results from 23 plant species inoculated with Papaya ringspot virus type Watermelon (PRSV-W), Watermelon mosaic virus (WMV) and Zucchini yellow mosaic virus (ZYMV).

\begin{tabular}{|c|c|c|c|c|c|c|}
\hline \multirow{2}{*}{ Family/Species/Cultivar } & \multicolumn{2}{|c|}{ PRSV-W } & \multicolumn{2}{|c|}{ WMV } & \multicolumn{2}{|c|}{ ZYMV } \\
\hline & $\mathrm{SR}^{1}$ & ELISA $^{2}$ & SR & ELISA & SR & ELISA \\
\hline \multicolumn{7}{|l|}{ Amaranthaceae } \\
\hline Gomphrena globosa $\mathrm{L}$. & WS & 0.7 & $\mathrm{ChL}$ & 14.4 & $\mathrm{ChL}$ & 0.6 \\
\hline \multicolumn{7}{|l|}{ Brassicaceae } \\
\hline Raphanus sativus L. & WS & 1.1 & WS & 1.1 & WS & 0.9 \\
\hline \multicolumn{7}{|l|}{ Chenopodiaceae } \\
\hline Chenopodium amaranticolor Costa and Reyn & LL & 0.9 & $\mathrm{ChL}$ & 18.9 & $\mathrm{ChL}$ & 0.8 \\
\hline C. murale $\mathrm{L}$. & $\mathrm{ChL}$ & 0.9 & YP & 0.9 & YP & 0.9 \\
\hline C. quinoa Willd & $\mathrm{ChL}$ & 1.1 & $\mathrm{NeL}$ & 1.8 & $\mathrm{ChL}$ & 1.0 \\
\hline \multicolumn{7}{|l|}{ Caricaceae } \\
\hline Carica papaya L. 'Sunrise Solo' & WS & 0.8 & WS & 1.0 & WS & 0.9 \\
\hline \multicolumn{7}{|l|}{ Cucurbitaceae } \\
\hline Luffa cylindrica M. Roem. & WS & 1.6 & WS & 1.9 & WS & 1.7 \\
\hline L. operculata (L.) Cogn) & M & 19.9 & M & 38.4 & LD & 28.2 \\
\hline Cucumis anguria $\mathrm{L}$. & M & 18.5 & M & 3.5 & $\begin{array}{l}\text { MS/ } \\
\text { LD }\end{array}$ & 9.5 \\
\hline \multicolumn{7}{|l|}{ Citrullus lanatus } \\
\hline 'Smile' & $\mathrm{M}$ & 10.1 & M & 5.0 & $\mathrm{M}$ & 9.0 \\
\hline 'Crimson Sweet' & WS & 0.5 & MM & 14.8 & MM & 1.5 \\
\hline 'Omaru Yamato' & SM & 14.6 & M & 15.8 & $\begin{array}{l}\mathrm{SM} / \\
\mathrm{LD}\end{array}$ & 1.6 \\
\hline C. lanatus var. citroides & M & 8.5 & M & 4.0 & MM & 2.0 \\
\hline C. melo 'Imperial' & M & 18.7 & M & 1.0 & SM & 4.7 \\
\hline Cucurbita moschata 'Mogango' & $\begin{array}{l}\mathrm{MS} / \mathrm{B} \\
/ \mathrm{LD}\end{array}$ & 19.5 & ML & 21.4 & SM & 6.0 \\
\hline C. metuliferus L. 'Pepino africano' & MM & 1.1 & M & 1.3 & SM & 1.3 \\
\hline \multicolumn{7}{|l|}{ Fabaceae } \\
\hline Pisum sativum L. 'Torta de Flor Roxa' & WS & 0.8 & WS & 0.8 & WS & 1.2 \\
\hline \multicolumn{7}{|l|}{ Solanaceae } \\
\hline Solanum melongena L. 'Berinjela Preta' & WS & 0.8 & WS & 0.7 & WS & 1.0 \\
\hline Datura stramonium L. & WS & 1.0 & WS & 1.0 & WS & 1.0 \\
\hline Nicotiana benthamiana $\mathrm{L}$. & WS & 0.8 & WS & 0.5 & WS & 0.6 \\
\hline \multicolumn{7}{|l|}{ N. tabacum L. } \\
\hline 'Sansum' & WS & 1.1 & WS & 1.0 & WS & 0.9 \\
\hline 'White Burley' & WS & 1.2 & WS & 1.0 & WS & 1.4 \\
\hline var. Xanthi & WS & 0.7 & WS & 0.7 & WS & 0.9 \\
\hline \multirow{2}{*}{\multicolumn{7}{|c|}{ Solanum lycopersicum L. }} \\
\hline & & & & & & \\
\hline Híbrido SM-16 & WS & 1.1 & WS & 1.3 & WS & 1.3 \\
\hline 'Santa Clara' & WS & 1.2 & WS & 1.1 & WS & 1.5 \\
\hline 'Santa Cruz’ & WS & 1.2 & WS & 1.1 & WS & 1.1 \\
\hline \multicolumn{7}{|l|}{ Malvaceae } \\
\hline Abelmoschus esculentus L. Moench 'Santa Cruz' & WS & 2.2 & WS & 0.8 & WS & 0.7 \\
\hline \multicolumn{7}{|l|}{ Pedaliaceae } \\
\hline Sesamum indicum $\mathrm{L}$. & WS & 1.1 & WS & 6.3 & WS & 0.7 \\
\hline
\end{tabular}

Plants inoculated with ZYMV alone and with its combination with CMV presented similar symptoms. Kim et al. (2010) observed that the symptoms in $C$. pepo plants doubly infected with ZYMV and CMV in the field were peculiarly similar to those symptoms caused by CMV alone. According to Moreira, Filho and Rezende (2015) mixed virus infections in cucurbits are very common in natural conditions and can present biological and epidemiological variations, resulting in several effects on the infected hosts, as well as distinct levels of virus accumulation in the infected host tissues. 


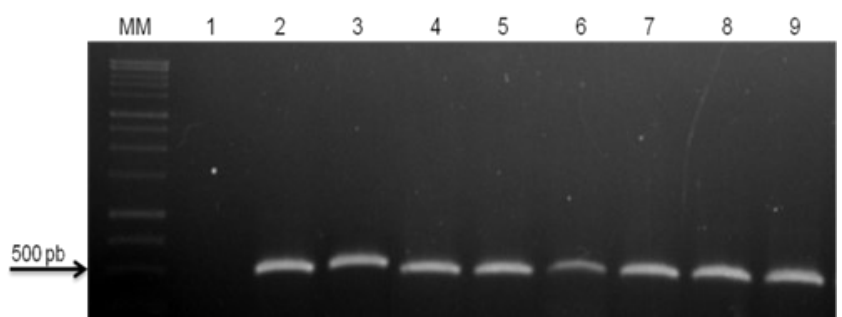

Figure 1. Amplified Cucumber mosaic virus (CMV) RNA from single infections and mixed infection with viruses from the Potyvirus genus in Cucurbita pepo 'Caserta' plants. MM-DNA $1 \mathrm{~Kb}$ marker Promega ${ }^{\circledR}$; 1 - healthy C. pepo; 2- C. pepo inoculated with CMV; 3- C. pepo inoculated with CMV + PRSV-W; 4- C. pepo inoculated with CMV + ZYMV; 5- C. pepo inoculated with CMV + WMV; 6- C. pepo inoculated with CMV + PRSV-W + ZYMV; 7- C. pepo inoculated with CMV + PRSV-W + WMV; 8- C. pepo inoculated with CMV + ZYMV + WMV; 9- C. pepo inoculated with CMV + PRSV-W + ZYMV + WMV.

In others mixed infections with CMV and species of the Potyvirus genus, CMV was present in low concentrations as assessed by PTA-ELISA; herein, the virus was also detected by RT-PCR (Figure 1). Choi et al. (2002) also used RT-PCR to demonstrate low levels of CMV in experiments involving co-infection with ZYMV. They observed that CMV could neutralize resistance to Potyvirus, which did not result in any increase in CMV concentration, potentially through inhibition of CMV replication; this is what probably occurred in the present study. Although some mixed virus infections result in severe diseases, others induce the disease symptoms of only one of the viruses involved, seemingly masking typical symptoms induced by the other virus (MURPHY; BOWEN, 2006).

Significant differences $(\mathrm{P}>0.05)$ were observed among the virus combinations for stem heights and fresh masses (Table 2). With the exception of those inoculated with the combinations PRSV-W + CMV and ZYMV + WMV + CMV, all plants inoculated with two, three, or four viruses presented high severity in the disease symptoms, presenting as physiological disturbances with significant reductions in height. Such results also indicate synergistic interactions dependent on the virus species. In contrast to the results obtained for the stem height, $C$. pepo plants infected with one or more viruses presented a lower fresh mass than the non-inoculated healthy plants, except for plants inoculated only $\mathrm{CMV}$, which had a lower fresh mass percent reduction. In addition, a fresh mass reduction of approximately $63 \%$ was observed in those plants inoculated with all four virus species (Table 2).

Based on the equation $\mathrm{C}_{\mathrm{WT}}=\mathrm{A}+\mathrm{B}$ $(\mathrm{AB} / 100)$, the responses for the six mixed infection combinations were higher than the waited responses, indicating a synergistic effect for the fresh masses and stem heights of the evaluated plants. No indication of synergism was observed with mixed infections of ZYMV + CMV and ZYMV + WMV + CMV in relation to fresh masses and plant heights, respectively. The observed responses for the combination PRSV-W + WMV + CMV were lower for both evaluated parameters and synergism was not observed for PRSV-W + ZYMV + WMV + CMV, as no waited response was obtained for this virus combination. However, the modified equations are only indicative of the type of response wherein $\mathrm{C}_{\mathrm{OBS}}$ $>\mathrm{C}_{\mathrm{WT}}$ indicates synergism and $\mathrm{C}_{\mathrm{OBS}}<\mathrm{C}_{\mathrm{WT}}$ indicates antagonism (MURPHY; BOWEN, 2006).

According to synergism determined by the height and the fresh mass of plants infected with two or more viruses, parameters that are associated with the disease symptom severity, it was observed that the C. pepo 'Caserta' plants infected with three or four viruses exhibited the most severe disease compared to that of plants infected with only one virus. This suggests a synergistic interaction between the virus species, which was mainly observed among species of the Potyvirus genus. Some negative interference was observed for these species with CMV. 
Table 2. Stem height and fresh mass of non-inoculated (negative control) and inoculated Cucurbita pepo 'Caserta' plants with Papaya ringspot virus type Watermelon (PRSV-W), Watermelon mosaic virus (WMV), Zucchini yellow mosaic virus (ZYMV), and Cucumis mosaic virus (CMV), individually or in combinations.

\begin{tabular}{|c|c|c|}
\hline Virus Infection & Stem Height $(\mathrm{cm})$ & Fresh Mass (g) \\
\hline A. Cucurbita pepo 'Caserta' - Healthy & $31.1 \mathrm{a}$ & $14.6 \mathrm{a}$ \\
\hline PRSV-W & $30.8 \mathrm{a}$ & $8.2 \mathrm{~b}$ \\
\hline ZYMV & $30.0 \mathrm{a}$ & $5.8 \mathrm{~b}$ \\
\hline WMV & $27.3 \mathrm{a}$ & $9.7 \mathrm{~b}$ \\
\hline CMV & $27.5 \mathrm{a}$ & $14.2 \mathrm{a}$ \\
\hline PRSV-W + CMV & $26.8 \mathrm{a}$ & $7.0 \mathrm{~b}$ \\
\hline ZYMV + CMV & $20.6 \mathrm{c}$ & $6.0 \mathrm{~b}$ \\
\hline $\mathrm{WMV}+\mathrm{CMV}$ & $20.5 \mathrm{c}$ & $10.2 \mathrm{~b}$ \\
\hline PRSV-W + ZYMV + CMV & $24.5 \mathrm{~b}$ & $6.4 \mathrm{~b}$ \\
\hline PRSV-W + WMV + CMV & $24.4 \mathrm{~b}$ & $9.3 \mathrm{~b}$ \\
\hline $\mathrm{ZYMV}+\mathrm{WMV}+\mathrm{CMV}$ & $28.2 \mathrm{a}$ & $7.8 \mathrm{~b}$ \\
\hline PRSV-W + ZYMV + WMV + CMV & $19.5 \mathrm{c}$ & $5.4 \mathrm{~b}$ \\
\hline \multicolumn{3}{|l|}{ B. Percent reduction compared to control ${ }^{\mathrm{x}}$} \\
\hline PRSV-W & 1.0 & 43.8 \\
\hline ZYMV & 3.5 & 60.3 \\
\hline WMV & 12.2 & 33.6 \\
\hline CMV & 11.6 & 2.7 \\
\hline PRSV-W + CMV $\left(\mathrm{C}_{\mathrm{OBS}}\right)^{\mathrm{y}}$ & 13.8 & 52.0 \\
\hline $\mathrm{ZYMV}+\mathrm{CMV}\left(\mathrm{C}_{\mathrm{OBS}}\right)^{\mathrm{y}}$ & 33.8 & 59.0 \\
\hline $\mathrm{WMV}+\mathrm{CMV}\left(\mathrm{C}_{\mathrm{OBS}}\right)^{\mathrm{y}}$ & 34.1 & 30.1 \\
\hline $\mathrm{PRSV}-\mathrm{W}+\mathrm{ZYMV}+\mathrm{CMV}\left(\mathrm{C}_{\mathrm{OBS}}\right)^{\mathrm{y}}$ & 21.2 & 56.2 \\
\hline PRSV-W + WMV + CMV $\left(\mathrm{C}_{\mathrm{OBS}}\right)^{\mathrm{y}}$ & 21.5 & 36.3 \\
\hline $\mathrm{ZYMV}+\mathrm{WMV}+\mathrm{CMV}\left(\mathrm{C}_{\mathrm{OBS}}\right)^{\mathrm{y}}$ & 9.3 & 46.6 \\
\hline $\mathrm{PRSV}-\mathrm{W}+\mathrm{ZYMV}+\mathrm{WMV}+\mathrm{CMV}\left(\mathrm{C}_{\mathrm{OBS}}\right)^{\mathrm{y}}$ & 37.3 & 63.0 \\
\hline PRSV-W + CMV $\left(\mathrm{C}_{\mathrm{WT}}\right)^{\mathrm{z}}$ & 11.9 & 43.8 \\
\hline $\mathrm{ZYMV}+\mathrm{CMV}\left(\mathrm{C}_{\mathrm{WT}}\right)^{\mathrm{Z}}$ & 14.7 & 61.4 \\
\hline $\mathrm{WMV}+\mathrm{CMV}\left(\mathrm{C}_{\mathrm{WT}}\right)^{\mathrm{z}}$ & 22.4 & 22.5 \\
\hline $\mathrm{PRSV}-\mathrm{W}+\mathrm{ZYMV}+\mathrm{CMV}\left(\mathrm{C}_{\mathrm{WT}}\right)^{\mathrm{z}}$ & 16.3 & 35.5 \\
\hline PRSV-W + WMV + CMV $\left(\mathrm{C}_{\mathrm{WT}}\right)^{\mathrm{z}}$ & 23.2 & 40.4 \\
\hline $\mathrm{ZYMV}+\mathrm{WMV}+\mathrm{CMV}\left(\mathrm{C}_{\mathrm{WT}}\right)^{\mathrm{z}}$ & 22.3 & 41.9 \\
\hline $\mathrm{PRSV}-\mathrm{W}+\mathrm{ZYMV}+\mathrm{WMV}+\mathrm{CMV}\left(\mathrm{C}_{\mathrm{WT}}\right)^{\mathrm{z}}$ & 23.3 & - \\
\hline
\end{tabular}

${ }^{\mathrm{x}}$ Percent reduction compared to control (healthy); ${ }^{\mathrm{y}} \mathrm{C}_{\mathrm{OBS}}=$ observed response and ${ }^{\mathrm{z}} \mathrm{C}_{\mathrm{WT}}=$ waited response: $\mathrm{C}_{\mathrm{WT}}=\mathrm{A}+\mathrm{B}-$ $(\mathrm{AB} / 100)$ or $\mathrm{A}+\mathrm{B}+\mathrm{C}-(\mathrm{ABC} / 100)$ or $\mathrm{A}+\mathrm{B}+\mathrm{C}+\mathrm{D}-(\mathrm{ABCD} / 100)$, for double, triple and quadruple infection, respectively, where A, B, C, and D represent PRSV-W, ZYMV, WMV, and CMV, in this order.

\section{CONCLUSIONS}

Our results confirmed the high and prevailing occurrence of viruses from the Potyvirus genus in mixed infections in cultivated cucurbit fields in the San Francisco Valley.

The host range studies indicated that Sesamum indicum could be used as an indicator plant for WMV and could function as a source of the virus in the field.

The designed primers for the virus from the Potyvirus genus could be used to detect PRSV-W, WMV, and ZYMV in infected plant tissues according to different sizes of the amplified DNA fragments.

The interaction studies in C. pepo 'Caserta' indicated synergistic interactions between PRSV-W, WMV, and ZYMV and some negative interference with CMV.

\section{ACKNOWLEDGMENTS}

We are thankful to Aline Kelly Queiróz Nascimento, Laianny Morais Maia, Fabiana Rodrigues da Silva, and Ana Kelly Firmino da Silva for their support in performing and evaluating the experiments.

\section{REFERENCES}

AL-SALEH, M. A. et al. Characterization of different isolates of Zucchini yellow mosaic virus from cucurbits in Saudi Arabia. African Journal of Microbiology Research, Lagos, v. 8, n. 19, p. 1987-1994, 2014.

BARBA, M.; JELKMAN, W.; MARTIN, R. Detection of virus and virus-like diseases of fruit trees and small fruit crops. Acta Horticulturae, The 
Hague, v. 2, n. 472, p. 759-783, 1998.

CHOI, S. K. et al. Systemic movement of a movement-deficient strain of Cucumber mosaic virus in zucchini squash is facilitated by a cucurbit-infecting potyvirus. Journal of General Virology, London, v. 83, n. 12, p. 3173-3178, 2002.

CHOMCZYNSKI, P.; SACCHI, N. Single-step method of RNA isolation by acid guanidinium thiocyanate-phenol-chloroform extraction. Analytical Biochemistry, San Diego, v. 162, n. 1, p. 156-159, 1987.

COUTTS, B. A. et al. Zucchini yellow mosaic virus: biological properties, detection procedures and comparison of coat protein gene sequences. Archives of Virology, Wien, v. 156, n. 12, p. 2119-2131, 2011.

CRUZ, C. D. GENES - a software package for analysis in experimental statistics and quantitative genetics. Acta Scientiarum, Maringá, v. 35, n. 3, p. 271-276, 2013.

DESBIEZ, C.; LECOQ, H. Zucchini yellow mosaic virus. Plant Pathology, Oxford, v. 46, n. 6, p. 809-829, 1997.

FINETTI-SIALER, M. M. et al. Biological and molecular characterization of a recombinant isolate of Watermelon mosaic virus associated with a watermelon necrotic disease in Italy. European Journal of Plant Pathology, Dordrecht, v. 132, n. 3, p. 317-322, 2012.

GISI, U. Synergistic interaction of fungicides in mixtures. Phytopathology, Saint Paul, v. 86, n. 11, p. $1273-1279,1996$.

HOSSEINI, S. et al. Characterization of the Zucchini yellow mosaic virus from squash in Tehran province. Journal of Agricultural Science and Technology, Tehran, v. 9, n. 2, p. 137-143, 2007.

JUAREZ, M. et al. Relative incidence, spatial distribution and genetic diversity of cucurbit viruses in eastern Spain. Annals of Applied Biology, London, v. 162, n. 3, p. 362-370, 2013.

KIM, M. K. et al. Characteristics of Cucumber mosaic virus infecting zucchini in Korea. Plant Pathology Journal, Seoul, v. 26, n. 2, p. 139-148, 2010.

KUMAR, S.; SANKARLINGAM, A.; RABINDRAN, R. Characterization and Confirmation of Papaya ringspot virus-W strain Infecting Trichosanthese cucumerina at Tamil Nadu, India. Journal of Plant Pathology \& Microbiology,
Los Angeles, v. 5, n. 2, p. 225, 2014.

LIMA, J. A. A. et al. Serology Applied to Plant Virology. In: Moslih Al-Moslih. (Org.). Serological diagnosis of certain human, animal and plant diseases. Rijeka, Croatia: InTech, 1. p.71-94, 2012 b.

LIMA, J. A. A. et al. Virologia essencial \& viroses em culturas tropicais. 1. ed. Fortaleza, CE: Edições UFC. 2015. 605 p.

LIMA, J. A. A. et al. Viruses infecting melon and watermelon in Northeastern Brazil. Virus Reviews and Research, Rio de Janeiro, v. 17, n. 1, p. 29-35, 2012a.

MALIK, A. H. et al. Severe disease of melon in North West frontier province is associated with simultaneous infection of two RNA viruses. Pakistan Journal of Botany, Karachi, v. 42, n. 1, p. 361-367, 2010

MOREIRA, A. S.; FILHO, A. B.; REZENDE, J. A. M. Comparative epidemiology of three virus diseases on zucchini squash. Journal of Phytopathology, Berlin, v. 163, n. 5, p. 386-394. 2015.

MOWAT, W. P.; DAWSON, S. Detection of plant viruses by ELISA using crude sap extracts and unfractionated antisera. Journal of Virological Methods, Amsterdam, v. 15, n. 3, p. 233-247, 1987.

MURPHY, J. F.; BOWEN, K. L. Synergistic disease in pepper caused by the mixed infection of Cucumber mosaic virus and Pepper mottle virus. Phytopathology, Saint Paul, v. 96, n. 3, p. 240-247, 2006.

PINTO, Z. V. et al. Ability of Aphis gossypii and Myzus persicae to transmit Cucumber mosaic virus in single and mixed infection with two potyviruses to Zucchini Squash. Summa phytopathology, Botucatu, v. 34, n. 2, p. 183-185, 2008.

SILVA, F. R. et al. Caracterização biológica e sorológica de um isolado de Squash mosaic virus e efeitos da infecção mista com vírus do gênero Potyvirus. Revista Ciência Agronômica, Fortaleza, v. 47, n. 1, p. 195-202, 2016.

SILVEIRA, L. M. et al. Levantamento sorológico de vírus em espécies de cucurbitáceas na região do submédio São Francisco, Brasil. Tropical Plant Pathology, Brasília, v. 34, n. 2, p. 123-126, 2009.

YAKOUBI, S. et al. Molecular, biological and serological variability of Zucchini yellow mosaic virus in Tunisia. Plant Pathology, Oxford, v. 57, n. 6, p. 1146-1154, 2008. 